\title{
Versican Is Upregulated in CNS Injury and Is a Product of Oligodendrocyte Lineage Cells
}

\author{
Richard A. Asher, ${ }^{1,2}$ Daniel A. Morgenstern, ${ }^{1,2}$ Morven C. Shearer, ${ }^{1,2}$ Kathryn H. Adcock, ${ }^{1,2}$ Penka Pesheva, ${ }^{3}$ \\ and James W. Fawcett ${ }^{1,2}$ \\ ${ }^{1}$ Physiological Laboratory, University of Cambridge, Downing Site, Cambridge CB2 3EG, United Kingdom, ${ }^{2}$ Cambridge \\ Centre for Brain Repair, Forvie Site, Cambridge, CB2 2PY United Kingdom, and ${ }^{3}$ Neuro- and Tumor Cell Biology Group, \\ Department of Nuclear Medicine, University of Bonn, 53105 Bonn, Germany
}

Chondroitin sulfate proteoglycan (CS-PG) expression is increased in response to CNS injury and limits the capacity for axonal regeneration. Previously we have shown that neurocan is one of the CS-PGs that is upregulated (Asher et al., 2000). Here we show that another member of the aggrecan family, versican, is also upregulated in response to CNS injury. Labeling of frozen sections $7 \mathrm{~d}$ after a unilateral knife lesion to the cerebral cortex revealed a clear increase in versican immunoreactivity around the lesion. Western blot analysis of extracts prepared from injured and uninjured tissue also revealed considerably more versican in the injured tissue extract. In vitro studies revealed versican to be a product of oligodendrocyte lineage cells (OLCs). Labeling was seen between the late A2B5positive stage and the 01-positive pre-oligodendrocyte stage. Neither immature, bipolar A2B5-positive cells, nor differentiated, myelin-forming oligodendrocytes were labeled. The amount of versican in conditioned medium increased as these cells differentiated. Versican and tenascin- $R$ colocalized in OLCs, and coimmunoprecipitation indicated that the two exist as a complex in oligodendrocyte-conditioned medium. Treatment of pre-oligodendrocytes with hyaluronidase led to the release of versican, indicating that its retention at the cell surface is dependent on hyaluronate $(\mathrm{HA})$. In rat brain, approximately half of the versican is bound to hyaluronate. We also provide evidence of a role for CS-PGs in the axon growthinhibitory properties of oligodendrocytes. Because large numbers of OLCs are recruited to CNS lesions, these results suggest that OLC-derived versican contributes to the inhospitable environment of the injured CNS.

Key words: chondroitin sulfate; extracellular matrix; glial scar; hyaluronate; proteoglycan; regeneration; tenascin- $R$
Chondroitin sulfate proteoglycans (CS-PGs) inhibit axon growth in vitro (Snow et al., 1990; Dou and Levine, 1994; Friedlander et al., 1994; Milev et al., 1994; Yamada et al., 1997; Schmalfeldt et al., 2000) and are thought to create exclusion zones for growing axons in the embryo (Snow et al., 1990; Oakley and Tosney, 1991; Brittis et al., 1992; Emerling and Lander, 1996). Their increased expression in CNS injuries may therefore limit the capacity for axon regeneration (McKeon et al., 1991; Pindzola et al., 1993; Lips et al., 1995; Gates et al., 1996; Davies et al., 1997, 1999; Fitch and Silver, 1997). Various CS-PGs have been shown to be present at sites of CNS injury, including NG2 (Levine, 1994), phosphacan (Laywell and Steindler, 1991; McKeon et al., 1995; Barker et al., 1996; Deller et al., 1997; McKeon et al., 1999), neurocan (Haas et al., 1999; McKeon et al., 1999; Asher et al., 2000), and brevican (Jaworski et al., 1999; Thon et al., 2000). Definitive evidence of an inhibitory role for these molecules in axon regeneration has been lacking. However, recent work has shown that infusion of the enzyme chondroitinase $\mathrm{ABC}$, which denudes the core protein of chondroitin sulfate, enables severed axons of the nigrostriatal tract to regrow, and in some cases to reach their original target,

\footnotetext{
Received June 1, 2001; revised Nov. 20, 2001; accepted Dec. 28, 2001.

This work was supported by the Medical Research Council, The Wellcome Trust, and the International Spinal Research Trust. We thank Dr. J. H. Rogers for helpful discussions, Dr. A. Oohira for the neurocan antibody, and Dr. J. M. Levine for the NG2 antibody.

Correspondence should be addressed to Dr. Richard A. Asher, Cambridge Centre for Brain Repair, Forvie Site, Robinson Way, Cambridge, CB2 2PY, UK. E-mail: raa24@cam.ac.uk.

Copyright (ㄷ) 2002 Society for Neuroscience $0270-6474 / 02 / 222225-12 \$ 15.00 / 0$
}

the ipsilateral striatum (Moon et al., 2001). Chondroitinase also promoted regeneration of sensory axons in the dorsal columns of the spinal cord (Bradbury et al., 2000).

Versican belongs to the aggrecan family of hyaluronate (HA)binding CS-PGs. It was first identified in the adult CNS as the glial hyaluronate-binding protein (GHAP) (Perides et al., 1989), which was later shown to constitute the N-terminal (hyaluronatebinding) domain of versican (Zimmermann and Ruoslahti, 1989). GHAP is a naturally occurring fragment that is thought to be generated by the action of a matrix metalloproteinase(s) on versican (Perides et al., 1995). Versican is highly expressed in white matter tracts, and its expression is closely linked to myelination in the rat (Bignami et al., 1993). Four mRNA splice variants have been identified, the three largest of which, $V_{0}, V_{1}$, and $\mathrm{V}_{2}$, carry chondroitin sulfate (Dours-Zimmermann and Zimmermann, 1994). $V_{0}, V_{1}$, and $V_{2}$ have been identified in the human (Dours-Zimmermann and Zimmermann, 1994) and bovine brain (Schmalfeldt et al., 1998). In the adult bovine brain, the $\mathrm{V}_{2}$ isoform is by far the most abundant (Schmalfeldt et al., 1998).

Versican interacts primarily with other components of the extracellular matrix (ECM). Versican binds to hyaluronate via its N-terminal globular domain (LeBaron et al., 1992). The C-terminal globular domain mediates binding to tenascin-R (Aspberg et al., 1995), fibulin-1 (Aspberg et al., 1999), and certain sulfated glycolipids (Miura et al., 1999).

Recently, bovine spinal cord-derived versican has been shown to inhibit axon growth in vitro (Niederöst et al., 1999; Schmalfeldt 
et al., 2000). Oligodendrocytes in vitro labeled for versican and treatment with proteoglycan synthesis inhibitors led to the loss of cell surface versican and abolished the growth cone collapsing activity of these cells (Niederöst et al., 1999). Clearly, these findings point to an inhibitory role for versican in axon growth. In this study, we set out to establish (1) whether versican is upregulated in the damaged CNS, (2) which cells might be responsible for its presence, (3) what factors affect its expression, (4) with what does it associate in the ECM, and (5) whether CS-PGs contribute to the axon growth-inhibitory properties of oligodendrocytes.

Some of these data have been published previously in abstract form (Asher et al., 1999).

\section{MATERIALS AND METHODS}

\section{Surgical procedures}

Adult female Sprague Dawley rats (Charles River, Margate, Kent, UK; approximate body weight $200 \mathrm{gm}$ ) were anesthetized under Fluorothane, and the head was held in a stereotaxic apparatus with the incisor bar 2.5 $\mathrm{mm}$ below the interaural line. A fine scalpel blade was inserted stereotaxically and vertically into the brain, through a parasagittal dorsal craniotomy, to a depth of $3 \mathrm{~mm}$ below the dura and 2-3 $\mathrm{mm}$ lateral to the midline. The knife was then moved in the horizontal plane to produce a lesion $4-5 \mathrm{~mm}$ in length, midway between lambda and bregma. The operation was performed unilaterally (on the right-hand side) with the other hemisphere serving as a control. After 7-28 d, the animals were terminally anesthetized with an intraperitoneal injection of $0.7 \mathrm{ml}$ of sodium pentabarbitone and decapitated. The brain was rapidly removed and immediately frozen on dry ice or prepared for frozen sectioning.

\section{Immunolabeling of frozen sections}

Frozen, coronal sections $(10 \mu \mathrm{m})$ were cut from unfixed tissue 7 and $14 \mathrm{~d}$ post-lesion (dpl). Labeling was performed without fixation. Nonspecific binding was blocked with PBS containing 3\% BSA and $20 \mathrm{~mm}$ L-lysine (PBS/BSA/Lys). The sections were incubated with the anti-versican monoclonal antibody $(\mathrm{mAb}) 12 \mathrm{C} 5$ (undiluted hybridoma-conditioned medium) (Asher et al., 1991) or a mouse myeloma-derived $\mathrm{IgG}_{1}$ (Sigma, Poole, Dorset, UK; $11 \mu \mathrm{g} / \mathrm{ml}$ in PBS/BSA/Lys) for $1 \mathrm{hr}$. Bound antibodies were visualized with biotinylated anti-mouse immunoglobulins (1:100; Amersham, Little Chalfont, Bucks, UK) and Cy3-streptavidin $(1.0 \mu \mathrm{g} / \mathrm{ml}$; Amersham) in the manner described previously (Asher et al., 1995).

\section{Sample preparation for SDS-PAGE}

Brain tissue. Dissection was performed as rapidly as possible while the brain was still semifrozen. A piece of tissue $\sim 2 \times 4 \times 6 \mathrm{~mm}$ containing the lesion was excised. A similar sized piece was dissected from the same location on the uninjured side. The tissue was immediately placed in 1.0 $\mathrm{ml}$ of ice-cold extraction buffer [0.05 M Tris-HCl, $\mathrm{pH} 7.0,0.15 \mathrm{M} \mathrm{NaCl}$, $1 \%$ SDS and Complete protease inhibitor mixture (Roche, Lewes, East Sussex, UK)], and homogenized in a Teflon-glass Dounce homogenizer. The homogenates were centrifuged at $13,000 \times \mathrm{g}$ for $10 \mathrm{~min}$ at $4^{\circ} \mathrm{C}$. Protein measurements were made with the BCA Protein Assay Kit (Pierce, Chester, Cheshire, UK).

Cultured cells. Serum-free conditioned medium was removed from the cells, and Complete protease inhibitors were added immediately. The conditioned medium was then centrifuged $(1000 \times g$ for $5 \mathrm{~min})$ and concentrated in a Centricon 100 (Millipore, Watford, Herts, UK) to approximately one-tenth of its initial volume. The protein content was determined using the Coomassie Plus Protein Assay Reagent (Pierce). Chondroitinase ABC (protease-free; Roche) digestion was performed for $3 \mathrm{hr}$ at $37^{\circ} \mathrm{C}$ using $0.01 \mathrm{U}$ of enzyme per milliliter of conditioned medium.

For the preparation of detergent lysates, cells were washed twice with PBS and then solubilized in a small volume $\left(\sim 0.25 \mathrm{ml} / 25 \mathrm{~cm}^{2}\right.$ flask $)$ of 0.05 M Tris-HCl, pH 7.0, $0.15 \mathrm{M} \mathrm{NaCl}$ containing 1\% NP-40 (Calbiochem, Nottingham, Notts, UK), and Complete protease inhibitors. The cells were removed with a cell scraper and placed on a gyro-rocker at $4^{\circ} \mathrm{C}$ for $1 \mathrm{hr}$. The lysate was then centrifuged at $13,000 \times \mathrm{g}$ for $10 \mathrm{~min}$ at $4^{\circ} \mathrm{C}$. The supernatant is henceforth referred to as the detergent lysate. The protein content was determined with the BCA Protein Assay Kit (Pierce).

\section{Electrophoresis and Western blotting}

SDS-PAGE was performed in the manner described previously (Asher et al., 2000). Proteins were transferred to nitrocellulose (Hybond-C pure, Amersham) or polyvinyldifluoride (Hybond-P, Amersham) at $4^{\circ} \mathrm{C}$ for $15-18 \mathrm{hr}$, at a constant current of $150 \mathrm{~mA}$.

All subsequent procedures were performed at room temperature. The blots were rinsed twice in Tris-buffered saline (TBS; $0.9 \% \mathrm{NaCl}, 10 \mathrm{~mm}$ Tris-HCl, pH 7.5) containing $0.05 \%$ Tween 20 (TBS/Tween) and incubated for a further $40 \mathrm{~min}$ in TBS/Tween. All washes and antibody incubations were performed in TBS/Tween. The blots were then incubated with the anti-versican mAb 12C5 (hybridoma-conditioned medium diluted 1:60), the anti-neurocan mAb 1G2 (hybridoma-conditioned medium diluted 1:60) (Oohira et al., 1994), an anti-brevican mAb (250 $\mathrm{ng} / \mathrm{ml}$; Transduction Labs, San Diego, CA), an anti-tenascin-R mAb (1.5 $\mu \mathrm{g} / \mathrm{ml}$ ) (Pesheva et al., 1989), mouse $\operatorname{IgG}_{1}(1.1 \mu \mathrm{g} / \mathrm{ml})$, or rabbit antiNG2 proteoglycan $(1.0 \mu \mathrm{g} / \mathrm{ml}$ ) (gift of J. Levine, State University of New York, Stony Brook, NY) for 2 hr. Reactive species were visualized with peroxidase-conjugated anti-mouse or anti-rabbit IgG $(100 \mathrm{ng} / \mathrm{ml}$; Vector, Peterborough, Cambs, UK) and a chemiluminescent substrate (ECL, Amersham).

\section{Immunoprecipitation}

Formalin-fixed Staphylococcus aureus cells (Pansorbin, Calbiochem) were preloaded with either the $12 \mathrm{C} 5$ anti-versican mAb or an antitenascin-R $\mathrm{mAb}$ via rabbit anti-mouse $\operatorname{IgG}_{\mathrm{FC}}$ (Jackson, West Grove, PA). Oligodendrocyte-conditioned medium was concentrated and precleared with fixed $S$. aureus cells preloaded with rabbit anti-mouse $\operatorname{IgG}_{\mathrm{FC}}$. The preloaded $S$. aureus cells were then resuspended in the precleared conditioned medium and shaken on ice for $1 \mathrm{hr}$. The cells were washed six times in $50 \mathrm{~mm}$ Tris buffer, $\mathrm{pH} 7.5$, containing $0.5 \mathrm{~m}$ sodium chloride and $0.1 \%$ Tween 20 , and once in water. Immunoprecipitated proteins were eluted by boiling for $5 \mathrm{~min}$ in sample buffer and subjected to Western blot analysis.

\section{Glial cell culture}

All cell culture reagents were purchased from Invitrogen (Paisley, UK), unless stated otherwise. Primary glial cell cultures were prepared from the brains of newborn rats $<3 \mathrm{~d}$ old, as described previously (Asher et al., 2000).

Cultures enriched for oligodendrocyte lineage cells (OLCs) were derived from the cells dislodged by shaking the primary culture. The resultant cell suspension was filtered through 35 and $15 \mu \mathrm{m}$ nylon mesh and then preplated on non-tissue culture plastic to deplete it of macrophages/microglia. The nonattached cells were washed once in $\mathrm{Ca}^{2+}$ - and $\mathrm{Mg}^{2+}$-free HBSS and dispensed into either 24-well plates containing poly-D-lysine-coated glass coverslips (for immunocytochemistry) or polyD-lysine-coated 6-well plates or $25 \mathrm{~cm}^{2}$ flasks (for biochemistry) in DMEM containing $10 \%$ FCS. The cells were allowed to adhere for 1-2 $\mathrm{hr}$, and the medium was changed to either DMEM containing $0.01 \%$ crystalline BSA, $5 \mu \mathrm{g} / \mathrm{ml}$ insulin, $50 \mu \mathrm{g} / \mathrm{ml}$ transferrin, $30 \mathrm{~nm}$ sodium selenite, $10 \mathrm{~nm}$ D-biotin (Sigma), $10 \mathrm{~nm}$ hydrocortisone (Collaborative Biomedical Products, Bedford, MA), and 3,3'5-triiodo-L-thyronine (Sigma) (=oligodendrocyte differentiation medium) (Gard et al., 1995), or DMEM containing BSA, insulin, transferrin, and sodium selenite (as above), and $10 \mathrm{ng} / \mathrm{ml}$ platelet-derived growth factor (PDGF-AB; R\&D, Abingdon, Oxon, UK) and $10 \mathrm{ng} / \mathrm{ml}$ fibroblast growth factor 2 (FGF2; Roche) (=division medium).

Astrocyte and meningeal cell cultures were prepared in the manner described previously (Asher et al., 2000). For the preparation of meningeal cell-conditioned medium, the cells were grown for $3 \mathrm{~d}$ in DMEM containing BSA, insulin, transferrin, sodium selenite, and $1 \%$ FCS.

\section{Functional assay}

Oligodendrocyte progenitor cells were grown on poly-D-lysine-coated 13 $\mathrm{mm}$ glass coverslips in differentiation medium for $33 \mathrm{hr}$. Chondroitinase ABC $(0.05 \mathrm{U} / \mathrm{ml}$; Roche) or vehicle (HBSS) was then added to the medium, and the plates were returned to the incubator for $3 \mathrm{hr}$. The cells were washed in PBS and fixed in $4 \%$ paraformaldehyde for $20 \mathrm{~min}$ at $4^{\circ} \mathrm{C}$. Sterile conditions were maintained throughout the digestion, fixation, and subsequent procedures. The cells were washed in PBS, and quenched with $50 \mathrm{~mm}$ L-lysine in PBS. The coverslips were then used as a substrate for the culture of dissociated neonatal (postnatal day 0-1) rat dorsal root ganglion (DRG) neurons (Skaper et al., 1990). These cells were grown in serum-free DMEM containing BSA, insulin, transferrin, sodium selen- 
ite, and NGF $(10 \mathrm{ng} / \mathrm{ml})$ for $40 \mathrm{hr}$. The cells were fixed in cold methanol and labeled with the anti-neurofilament-associated protein mAb 3A10 (hybridoma-conditioned medium diluted 1:4; Developmental Studies Hybridoma Bank, Iowa City, IA) (Serafini et al., 1996), biotinylated antimouse Ig, and Cy3-streptavidin in the manner described below.

\section{Quantification of axon growth}

An estimate of the extent of axon growth on chondroitinase-treated and untreated oligodendrocytes was obtained as follows. The number of 3A10-positive (neuronal) processes intersecting two parallel lines $2 \mathrm{~mm}$ from the edge of the coverslip was counted. An assay consisted of 16 coverslips, 8 of which were treated with chondroitinase. Hence, $n=8$ for each condition. To determine whether chondroitinase affected neuronal adhesion to the substrate, the number of 3A10-positive neurons was counted in a $1 \mathrm{~mm}$ band $2 \mathrm{~mm}$ from the edge of each coverslip (i.e., in the same region as the axon counts). Provided that the number of neurons is constant, this assay is a reliable guide to any difference in axon growth.

\section{Immunocytochemistry}

Oligodendrocyte lineage cells were grown on poly-D-lysine-coated glass coverslips. Versican labeling was performed at room temperature on living cells in Liebovitz's L-15 medium (Invitrogen) containing 2\% FCS (L-15/FCS). The cells were washed once in L-15/FCS and incubated with the $12 \mathrm{C} 5$ anti-versican $\mathrm{mAb}$ (hybridoma-conditioned medium diluted 1:1) for $20 \mathrm{~min}$. The cells were washed three times with L-15/FCS and then incubated with biotinylated anti-mouse $\mathrm{IgG}, \mathrm{Fc}_{\gamma}$ fragment specific (12 $\mu \mathrm{g} / \mathrm{ml}$; Jackson) for $20 \mathrm{~min}$. The cells were washed as before and incubated with Cy3-streptavidin $(1 \mu \mathrm{g} / \mathrm{ml})$ for $20 \mathrm{~min}$. The cells were washed as before and incubated with either the A2B5 (hybridomaconditioned medium diluted 1:1; American Type Culture Collection, Manassas, VA) or O1 (hybridoma-conditioned medium diluted 1:1; European Collection of Animal Cell Cultures, Salisbury, Wilts, UK) mAb for $20 \mathrm{~min}$. These antigens were visualized with FITC anti-mouse IgM ( $\mu$ chain specific, $15 \mu \mathrm{g} / \mathrm{ml}$; Jackson). Finally, the cells were washed three times in $\mathrm{L}-15 / \mathrm{FCS}$, once in PBS, and fixed in cold $\left(-20^{\circ} \mathrm{C}\right)$ methanol for $2 \mathrm{~min}$. Nuclei were labeled with Hoechst $33342(10 \mu \mathrm{g} / \mathrm{ml}$; Sigma) for 30 $\min$.

Double labeling for versican and hyaluronate and O1 and HA was performed on living cells as follows. The cells were washed once in L-15/FCS and incubated with $10 \mu \mathrm{g} / \mathrm{ml}$ biotinylated hyaluronate-binding protein (Seikagaku, Falmouth, MA) for $20 \mathrm{~min}$. The cells were washed three times and incubated with Cy3-streptavidin $(1.0 \mu \mathrm{g} / \mathrm{ml})$ for $20 \mathrm{~min}$. The cells were washed as before, labeled with $12 \mathrm{C} 5$ and FITC anti-mouse IgG $(10 \mu \mathrm{g} / \mathrm{ml}$; Dako, High Wycombe, Bucks, UK), or O1 and FITC anti-mouse $\operatorname{IgM}$ ( $\mu$ chain specific), and fixed in the manner described above.

Labeling for tenascin- $\mathrm{R}$ was performed on living cells with either monoclonal or polyclonal antibodies (Pesheva et al., 1989). Double labeling for tenascin-R and $\mathrm{A} 2 \mathrm{~B} 5$ or $\mathrm{O} 1$ was performed in the manner described above for versican/A2B5 using an anti-tenascin-R mAb. Versican/tenascin-R double labeling was performed on living cells using rabbit antibodies against tenascin-R $(20 \mu \mathrm{g} / \mathrm{ml})$ and FITC anti-rabbit IgG (15 $\mu \mathrm{g} / \mathrm{ml}$; Jackson), and the $12 \mathrm{C} 5$ anti-versican mAb, biotinylated anti-mouse Ig, and Cy3-streptavidin. Doing the versican labeling before the tenascin-R labeling made no difference to the outcome. Glial fibrillary acidic protein (GFAP) labeling was performed on methanol-fixed cells with rabbit anti-GFAP $(20 \mu \mathrm{g} / \mathrm{ml}$; Dako $)$ and FITC anti-rabbit IgG.

Sterile testicular hyaluronidase $(1.0 \mathrm{mg} / \mathrm{ml}$ stock in DMEM; type IV; Sigma) or Streptomyces hyaluronidase [100 turbidity reducing units (TRU)/ml stock in DMEM; Seikagaku] was added directly to cell cultures to yield a final concentration of 20,50 , or $100 \mu \mathrm{g} / \mathrm{ml}$ and 20 $\mathrm{TRU} / \mathrm{ml}$, respectively, and incubation continued for $3 \mathrm{hr}$ at $37^{\circ} \mathrm{C}$ in a $\mathrm{CO}_{2}$-containing atmosphere.

\section{Hyaluronidase release of rat brain versican}

Adult rat brains (Harlan Sera-Lab, Loughborough, Leics, UK) were finely chopped while still frozen and then homogenized, using a Teflonglass Dounce homogenizer, in $0.1 \mathrm{M}$ phosphate buffer, $\mathrm{pH}$ 5.3, containing $0.15 \mathrm{M} \mathrm{NaCl}$, Complete protease inhibitors, and $2 \mu \mathrm{g} / \mathrm{ml}$ pepstatin A (Calbiochem), at a ratio of $\sim 1 \mathrm{gm}$ of (wet) tissue per $7.0 \mathrm{ml}$ of buffer. The homogenate was kept on ice for $10 \mathrm{~min}$ and then centrifuged at $3000 \times$ $g$ for $10 \mathrm{~min}$ at $4^{\circ} \mathrm{C}$. The resultant supernatant constitutes the first saline extract. The pellet was rehomogenized four times in the manner described above, giving rise to supernatants $2,3,4$, and 5 . The final homogenate was incubated for $10 \mathrm{~min}$ at $37^{\circ} \mathrm{C}$ rather than $4^{\circ} \mathrm{C}$. The
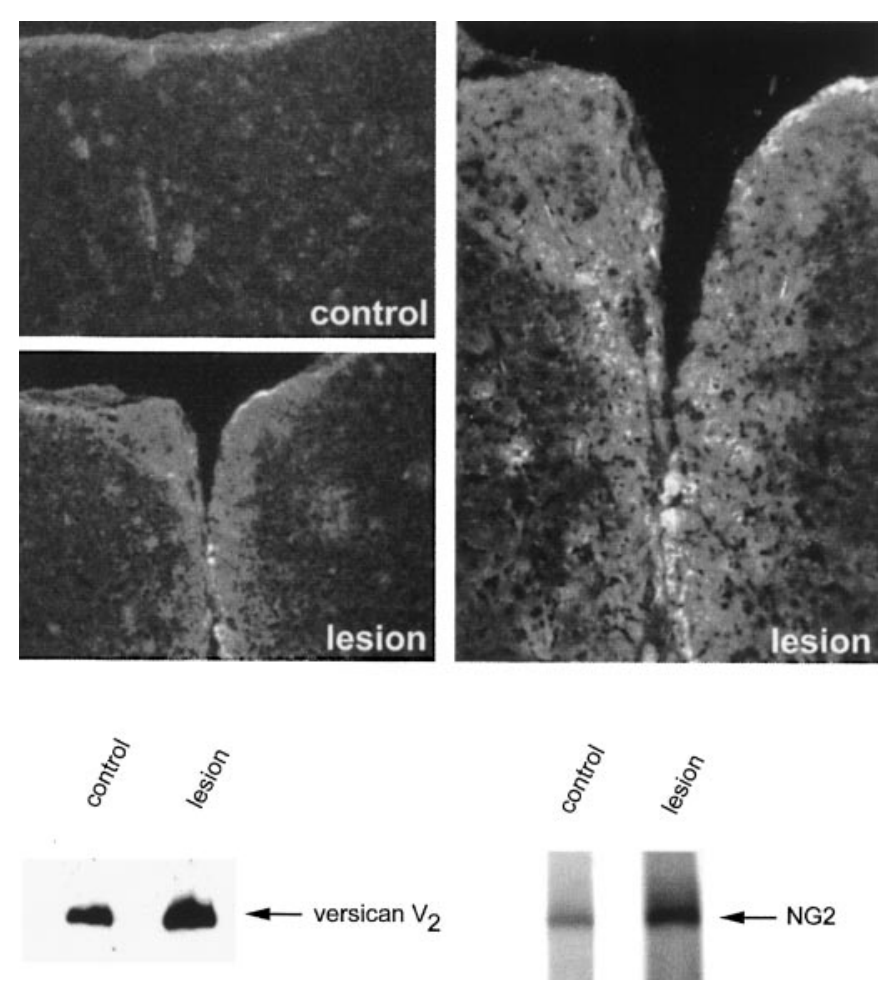

Figure 1. Versican is upregulated in the injured CNS. Top, Immunolocalization of versican in the injured CNS. Coronal frozen sections were labeled with the anti-versican mAb 12C5 $7 \mathrm{~d}$ after a knife cut lesion to the cerebral cortex. The dorsal surface of the brain is topmost. Labeling is apparent around the injury (lesion), which is clearly lacking on the uninjured side (control). Bottom, Western blot analysis of versican in the injured brain. SDS extracts were prepared from injured and uninjured cerebral cortex. The extracts were equalized for total protein $(162 \mu \mathrm{g})$, run in a $4 \%$ gel under nonreducing conditions, and transferred to polyvinylidene difluoride. The blot was labeled with the anti-versican $\mathrm{mAb}$ $12 \mathrm{C} 5$ and then with rabbit antibodies against the NG2 proteoglycan. An upregulation of both CS-PGs was clearly evident in the injured brain extracts.

homogenate was then divided into two equal parts, to only one of which was added testicular hyaluronidase (type IV; Sigma) to a final concentration of $50 \mu \mathrm{g} / \mathrm{ml}$. Both homogenates were incubated at $37^{\circ} \mathrm{C}$ for $2 \mathrm{hr}$. An aliquot was removed from each after $30 \mathrm{~min}$. The homogenates were then centrifuged for $10 \mathrm{~min}$ at $3000 \times g$, and the pellets were washed twice. Testicular hyaluronidase was added only to the homogenate not previously exposed to the enzyme, and both homogenates were incubated for a further $2 \mathrm{hr}$ at $37^{\circ} \mathrm{C}$. All of the supernatants (i.e., the five saline extracts and those with and without hyaluronidase) were clarified by centrifugation at $13,000 \times g$ for $10 \mathrm{~min}$ and frozen on dry ice. Chondroitinase digestion was performed by adding one-tenth volume 0.4 M Tris-acetate, $\mathrm{pH} 8.0$, and $0.025 \mathrm{U}$ chondroitinase $\mathrm{ABC}$ (Roche) per milliliter of supernatant and incubating for $3 \mathrm{hr}$ at $37^{\circ} \mathrm{C}$.

\section{RESULTS}

\section{Versican is upregulated in CNS injury}

We investigated versican expression in the injured CNS by immunohistochemistry and Western blotting. The distribution of versican was examined in unfixed frozen sections cut $7 \mathrm{~d}$ after a unilateral knife cut lesion to the cerebral cortex. An increase in versican labeling was seen around the lesion, in comparison with the uninjured side (Fig. 1). A similar increase in versican labeling was seen at $14 \mathrm{dpl}$. This increase was restricted to a region within $\sim 100 \mu \mathrm{m}$ of the knife cut. The appearance of the labeling was consistent with an extracellular matrix localization and could not be localized to a particular cell type. As reported previously, 
versican expression was low in the cerebral cortex but much higher in the subcortical white matter (Bignami et al., 1993). Versican labeling was also seen in the glia limitans and around some of the larger blood vessels.

For biochemical analysis, a piece of tissue $\sim 2 \times 4 \times 6 \mathrm{~mm}$ was dissected from around the lesion and from the equivalent region on the uninjured (contralateral) side. Care was taken to avoid the underlying white matter, in which versican is highly expressed. SDS extracts were prepared from the two pieces of tissue, and equivalent amounts of protein were run under nonreducing conditions in a $4 \%$ gel. Western blot analysis with the anti-versican mAb $12 \mathrm{C} 5$ revealed a single high $\mathrm{M}_{\mathrm{r}}$ species of $\sim 400 \mathrm{kDa}$ in injured and uninjured cortex (Fig. 1). This species comigrated with the versican isoform $\left(\mathrm{V}_{2}\right)$ found in normal rat CNS tissue and is the smallest of the three high $\mathrm{M}_{\mathrm{r}}$ species recognized by 12C5, all of which bear chondroitin sulfate (see Fig. 3). Quantification with NIH Image software revealed there to be two to three times more versican in the injured tissue extract at $7 \mathrm{dpl}$ (Fig. 1). A similar increase was evident at $14 \mathrm{dpl}$ but not at $28 \mathrm{dpl}$. This is likely to underestimate the extent of the upregulation, because the piece of tissue dissected from around the lesion was considerably larger than the region in which versican was seen to be upregulated in frozen sections.

To further characterize the GAG content of CNS versican, DEAE cellulose, an anion exchange resin, was used to partially purify CS-PGs from adult rat brain. The bound proteins were eluted with increasing concentrations of sodium chloride. These fractions were then assayed for versican by Western blotting. Most of the versican $\left(\mathrm{V}_{2}\right)$ was found in the 0.5 and $0.75 \mathrm{M} \mathrm{NaCl}$ fractions (see Fig. 5, bottom). For a given protein, the length and number of GAG chains will have a major influence on how well it binds to the anion exchange resin. An increase in the overall amount of GAG will lead to stronger binding and consequently require a higher salt concentration to remove it. Hence, the shift brought about by chondroitinase is more pronounced in the higher salt fractions, because they contain versican core proteins with a higher relative GAG content (see Fig. 5, bottom). Compared with other CNS CS-PGs, such as neurocan (Asher et al., 2000), versican carries relatively little chondroitin sulfate.

\section{Versican is a product of oligodendrocyte lineage cells in vitro}

A recent report has shown that in vitro, differentiated oligodendrocytes label with antibodies against versican (Niederöst et al., 1999). However, such cells could not account for the upregulation of versican in the gray matter of the injured cerebral cortex. We therefore examined versican expression in cells of the oligodendrocyte lineage at different stages of differentiation, and in astrocytes and meningeal cells, using immunocytochemistry and biochemical techniques.

\section{Immunocytochemistry}

Oligodendrocyte lineage cells

Oligodendrocyte lineage cells were removed from mixed glial cultures by shaking, and either plated directly in medium supportive of oligodendrocyte differentiation (Gard et al., 1995) or grown first for $2 \mathrm{~d}$ in medium containing PDGF and FGF2, which drives their division, before being switched to differentiation medium. The cells were double labeled with the anti-versican $\mathrm{mAb} 12 \mathrm{C} 5$, and with either the A2B5 or O1 mAb, after 1-5 d in culture. Such cultures contained cells at various stages of differentiation. For comprehensibility, we describe the labeling patterns by stage of differentiation.
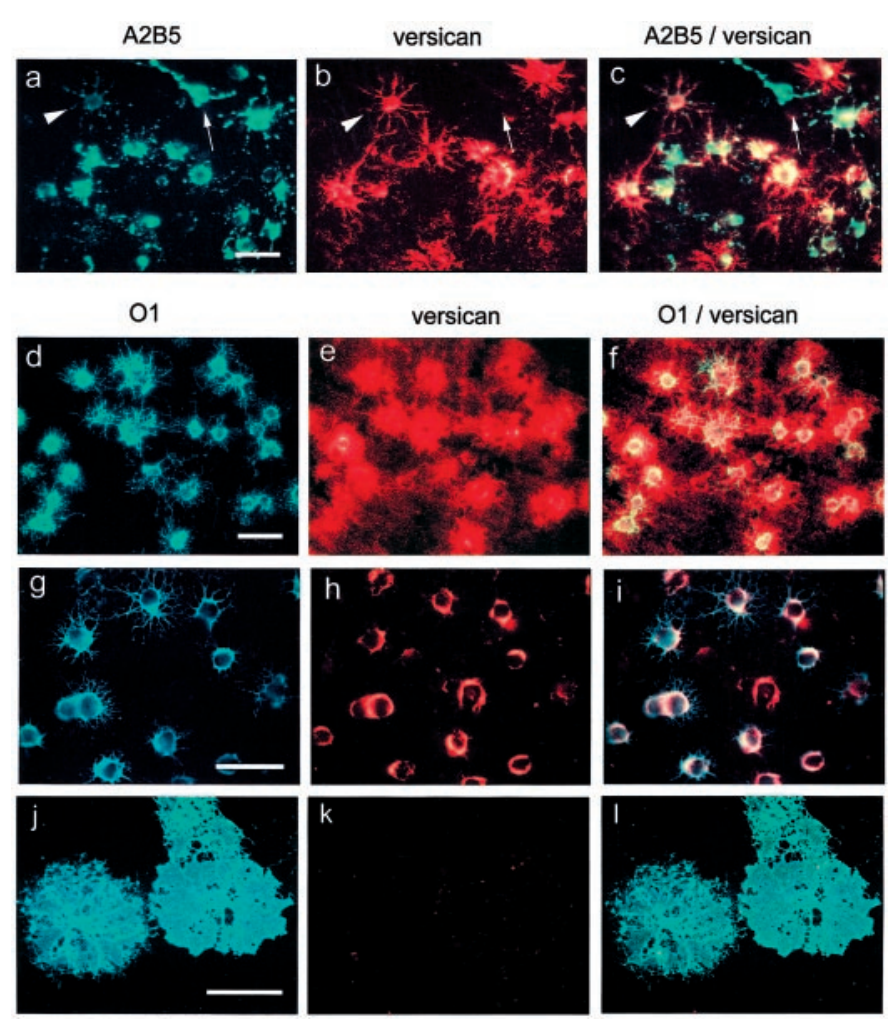

Figure 2. Pro-oligodendroblasts and pre-oligodendrocytes, but not bipolar oligodendrocyte precursor cells or myelin-forming oligodendrocytes, label for versican. OPCs were grown for $1 \mathrm{~d}(a-c), 2 \mathrm{~d}(d-f)$, or $5 \mathrm{~d}(j-l)$ in differentiation medium, or in division medium for $2 \mathrm{~d}$ and then in differentiation medium for $2 \mathrm{~d}(g-i)$. The cells were double labeled for A2B5 $(a)$ or $\mathrm{O} 1(d, g, j)$ and versican $(b, e, h, k)$. The two are shown together in the right-hand column $(c, f, i, l)$. The labeling was performed on living cells, and the cells were post-fixed in cold methanol. In OPCs plated directly in differentiation medium, versican is first seen to be associated with weakly A2B5-positive, multipolar cells ( $a-c$, arrowheads) and subsequently with O1-positive cells $(d-f)$. In OPCs grown initially in medium containing PDGF and FGF2 and then in differentiation medium, versican appears as a ring on the dorsal (top) cell surface $(g-i)$. Neither bipolar, A2B5-positive OPCs ( $a-c$, arrows) nor myelin-forming oligodendrocytes $(j-l)$ label for versican. Scale bars, $20 \mu \mathrm{m}$.

Oligodendrocyte progenitor cells $\left(\mathrm{A2B5}^{+}, \mathrm{O}^{-}, \mathrm{Ol}^{-}\right)$. Bipolar, A2B5-positive oligodendrocyte progenitor cells (OPCs) were invariably versican negative (Fig. $2 a-c$ ).

Pro-oligodendroblast $\left(\mathrm{A} \mathrm{B5}^{+}, \mathrm{O}_{4}^{+}, \mathrm{Ol}^{-}\right)$. Versican immunoreactivity first appeared on multipolar, weakly A2B5-positive cells. Two different labeling patterns were distinguishable, one of which was substrate associated and the other cell associated. The former took the form of slightly fuzzy, stellate profiles, the topography of which did not always correspond to the location of the processes of the accompanying cell (Fig. $2 a-c$ ). This material must be extracellular, because the labeling was performed on living cells. To determine whether the 12C5-reactive material is present on the cells or the substrate, the cells were removed with $1 \%$ NP-40 in water. The same 12C5-positive stellate profiles were seen in the absence of the cells. Much of this material is therefore associated with the substrate, rather than the cells themselves. The substrate-associated versican was also unaffected by treatment with $1 \mathrm{~mm}$ EDTA for $1 \mathrm{hr}$.

The other, cell-associated labeling pattern took the form of a ring, partly or wholly encircling the cell body. Again, this labeling is extracellular, because it was performed without any previous 
fixation. The ring-type labeling was seen in OPCs plated directly in differentiation medium, but at a much lower frequency than the substrate-associated labeling. The two types of labeling were occasionally seen in the same cell. The ring-type labeling was the predominant pattern, however, in cells expanded in PDGF and FGF2, and subsequently switched to differentiation medium (see below).

Pre-oligodendrocytes $\left(\mathrm{A} 2 \mathrm{B5}^{-}, \mathrm{O}^{+}, \mathrm{Ol}^{+}\right)$. Both types of versican labeling described above were also seen in multipolar, O1positive, A2B5-negative cells. The substrate-associated labeling took the form of an irregular, circular patch, at the periphery of which fuzzy processes were discernible (Fig. $2 d-f$ ). In growth factor-exposed cells, the ring-type labeling was the predominant pattern, in terms of both intensity and the number of cells involved (Fig. $2 g-i$ ). The processes of such cells were generally not labeled for versican. Growth factor-expanded, chondroitinase ABCtreated pre-oligodendrocytes were labeled with the 2B6 and 3B3 mAbs, which react with the "stubs" remaining after chondroitinase digestion of chondroitin-4-sulfate and chondroitin-6-sulfate, respectively. The 2B6 mAb, but not the 3B3 mAb, labeled O1positive pre-oligodendrocytes in a manner identical to that seen with the anti-versican $\mathrm{mAb}$, and it may therefore be concluded that the pre-oligodendrocyte-associated versican carries chondroitin-4sulfate. The CS-56 mAb, which reacts with an epitope peculiar to certain chondroitin sulfate chains, did not react with these cells.

Myelin-forming oligodendrocytes $\left(\mathrm{A2B5}^{-}, \mathrm{O}^{-}, \mathrm{Ol}^{+}\right)$. Myelinforming oligodendrocytes (i.e., O1-positive cells with large membranous sheets) were not labeled for versican (Fig. $2 j-l$ ). Without previous fixation, no labeling of the membranous sheets was seen, although vestiges of the ring-type labeling were occasionally seen on the cell body. A similar picture emerged in cells permeabilized by fixation in cold methanol before labeling (data not shown).

\section{Astrocytes}

Oligodendrocyte cultures inevitably contain astrocytes, some of which derive from OPCs (so-called type 2 astrocytes) and some of which result from contamination with monolayer-derived cells (type 1 astrocytes). No labeling for versican was ever seen on, or in the environs of, type 1 astrocytes (data not shown). Some versican labeling was seen, however, in a small proportion of what by morphological criteria were type 2 astrocytes. This labeling colocalized with the GFAP-positive processes of these cells.

\section{Meningeal cells}

The 12C5 mAb labeled fibronectin-positive cells derived from newborn rat brain meninges (data not shown). This labeling took the form of a fine reticular meshwork on the dorsal (upper) cell surface.

\section{Biochemistry}

The conditioned medium of purified cultures of oligodendrocyte lineage cells, astrocytes, meningeal cells, and microglia was assayed for the presence of versican by Western blotting with the $12 \mathrm{C} 5 \mathrm{mAb}$.

\section{Oligodendrocyte lineage cells}

Western blot analysis of chondroitinase-treated OLCconditioned medium with the $12 \mathrm{C} 5 \mathrm{mAb}$ revealed a single, very large $(\sim 400 \mathrm{kDa})$ species (Fig. 3). In contrast to the versican found in CNS tissues (Fig. 3), the OLC-derived species was unable to enter a $4 \%$ gel without previous chondroitinase ABC treatment (Fig. 3). It may therefore be concluded that the OLC-

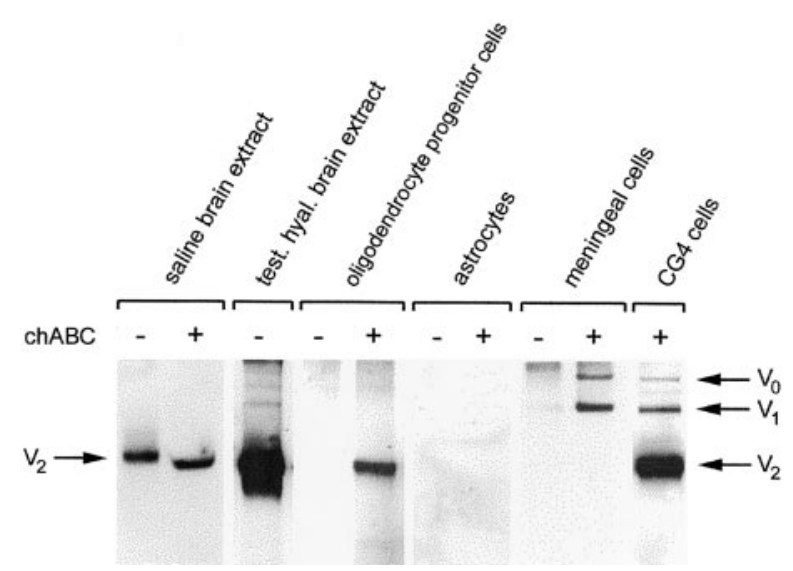

Figure 3. Oligodendrocytes produce the same versican isoform $\left(V_{2}\right)$ as that found in the rat CNS. The versican in adult rat brain (the $0.5 \mathrm{M} \mathrm{NaCl}$ fraction from DEAE-bound material; see Fig. 5) was compared with that in the conditioned medium of OLCs, astrocytes, meningeal cells, and the OPC-like cell line CG4. A testicular hyaluronidase (test. hyal.) extract of rat brain was overloaded to show that low levels of $\mathrm{V}_{0}$ and $\mathrm{V}_{1}$ are present in adult rat brain. OLCs make only the $\mathrm{V}_{2}$ isoform, which is unable to enter the gel without chondroitinase treatment. Astrocytes do not produce versican. Meningeal cells make only $\mathrm{V}_{0}$ and $\mathrm{V}_{1}$, both of which require chondroitinase digestion to enter the gel. As expected, CG4 cells make mostly $\mathrm{V}_{2}$, although small amounts of $\mathrm{V}_{0}$ and $\mathrm{V}_{1}$ were also detected.

derived versican bears more chondroitin sulfate than rat brain versican. The OLC-derived versican core protein (i.e., after chondroitinase treatment) comigrated with the versican isoform found in the adult rat CNS, i.e., $\mathrm{V}_{2}$ (Fig. 3). The amount of versican present in the conditioned medium of cells grown in differentiation medium was greater than that in cells in PDGF- and FGF2containing medium (Fig. 4), supporting the conclusion that versican expression increases when these cells exit the division cycle or commence differentiation or both.

The OPC-like cell line CG4 was also tested for versican expression and found to be capable of producing all three large versican isoforms (Fig. 3). The $\mathrm{V}_{2}$ isoform was by far the most abundant, indicating that the cells have remained primarily true to type as far as versican expression is concerned. Our ability to detect low levels of the $\mathrm{V}_{0}$ and $\mathrm{V}_{1}$ isoforms may be related to the high overall level of versican expression in these cells.

\section{Meningeal cells}

The $12 \mathrm{C} 5 \mathrm{mAb}$ recognized two species of $\mathrm{M}_{\mathrm{r}}$ higher than $400 \mathrm{kDa}$ in the conditioned medium of cultured meningeal cells, both of which failed to enter a $4 \%$ gel without previous chondroitinase treatment (Fig. 3). These species correspond to the $\mathrm{V}_{0}$ and $\mathrm{V}_{1}$ isoforms.

\section{Astrocytes and microglia}

No form of versican was detected in the conditioned medium of type 1 astrocytes (Fig. 3) (Asher et al., 2000). Neither was versican detectable in the conditioned medium of newborn rat brain-derived microglia (data not shown).

The 12C5 mAb therefore recognizes three large, chondroitin sulfate-bearing species. On the basis of their $\mathrm{M}_{\mathrm{r}}$, the two larger species produced by meningeal cells and CG4 cells correspond to the $\mathrm{V}_{0}$ and $\mathrm{V}_{1}$ isoforms, and the smaller ( $\left.\sim 400 \mathrm{kDa}\right)$ form, produced by cells of the oligodendrocyte lineage and CG4 cells, and the predominant form in the adult rat CNS, corresponds to the $\mathrm{V}_{2}$ isoform. 

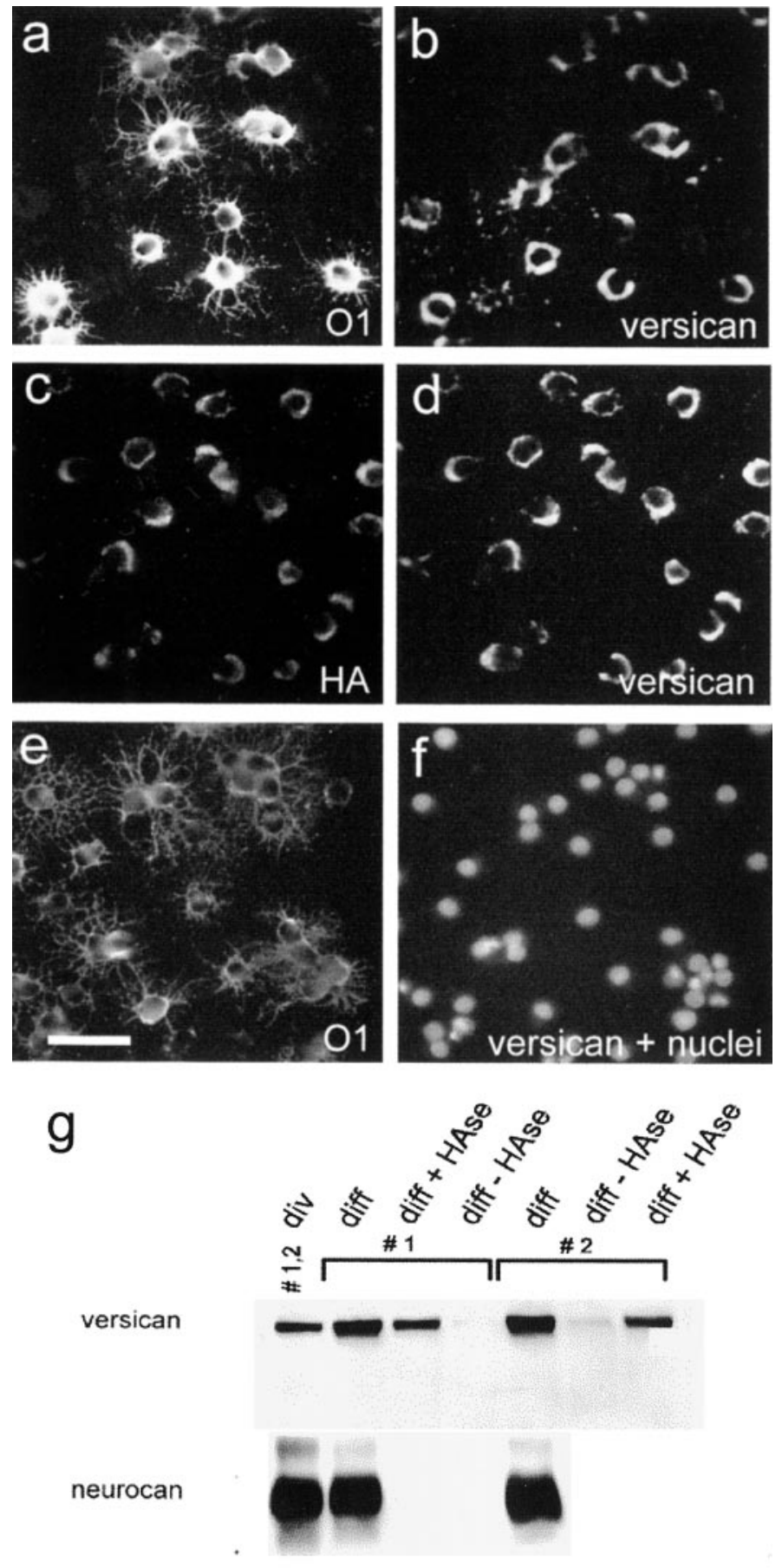

neurocan-C

brevican

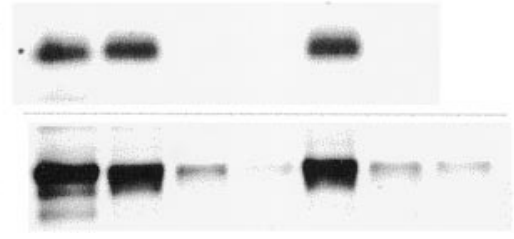

Figure 4. Versican binding to pre-oligodendrocytes is hyaluronatedependent. Pre-oligodendrocytes were double labeled for $\mathrm{O} 1$ and versican $(a, b)$, hyaluronate and versican $(c, d)$, and $\mathrm{O} 1$ and versican $(e, f)$. The cells shown in $e$ and $f$ were digested with Streptomyces hyaluronidase before labeling. Versican labeling takes the form of a ring, wholly or partly encircling the cell body of O1-positive pre-oligodendrocytes $(b, d)$. The distribution of hyaluronate is identical to that of versican $(c, d)$. Strepto-

\section{Versican is bound to hyaluronate in vitro and in vivo}

Versican binds hyaluronate in vitro (LeBaron et al., 1992), and there is evidence that it is associated with HA in vivo (Asher et al., 1991). We therefore investigated whether the binding of versican to oligodendrocyte lineage cells is mediated by HA. We also examined in greater detail the association of versican with HA in vivo.

\section{Oligodendrocyte lineage cells in vitro}

The biotinylated hyaluronate-binding domain of cartilage aggrecan was used to localize HA in oligodendrocyte lineage cells. In OLCs expanded in PDGF- and FGF2-containing medium and then allowed to differentiate, labeling for HA gave rise to a cell body-associated ring very similar to that seen with the antiversican $\mathrm{mAb}$. Double labeling for HA and versican revealed the two to be almost entirely coincident (Fig. $4 c, d$ ). In OLCs plated directly in oligodendrocyte differentiation medium, in which the predominant form of versican labeling is substrate associated, HA labeling gave rise only to the cell-associated, ring-like pattern (in a small proportion of the cells) and not to the substrate-associated type.

To determine whether the attachment of versican to the surface of these cells is mediated by HA, we pretreated the cells with hyaluronidase before versican labeling. The ring-type versican labeling in pre-oligodendrocytes was found to be sensitive to both testicular and Streptomyces hyaluronidases (Fig. 4e,f). HA labeling was also completely abolished by pretreatment of the cells with Streptomyces hyaluronidase. This enzyme is HA specific (Ohya and Kaneko, 1970), unlike testicular hyaluronidase, which also degrades chondroitin sulfate. Versican immunoreactivity was unaffected by chondroitinase $\mathrm{ABC}$. These findings imply that the binding of versican to the surface of these cells is mediated by HA. The substrate-associated labeling, however, was unaffected by hyaluronidase, implying that $\mathrm{HA}$ is not involved in the attachment of versican to the substrate.

If hyaluronidase indirectly liberates versican from the cell surface by degrading HA, then it ought to be possible to detect intact versican in the medium of hyaluronidase-treated cells. OLCs were expanded in PDGF- and FGF2-containing medium and then allowed to differentiate to the pre-oligodendrocyte stage. The culture medium was removed and replaced with either medium containing testicular hyaluronidase (flask 1) or medium alone (flask 2) for $1 \mathrm{hr}$. This medium was then removed, and a second

\footnotetext{
myces hyaluronidase abolished versican labeling ( $f$, shows Hoechstlabeled nuclei). Scale bar, $20 \mu \mathrm{m} . g$, Two $25 \mathrm{~cm}^{2}$ flasks of OPCs were grown for $2 \mathrm{~d}$ in medium containing PDGF and FGF2 (div). This medium was then changed to one supportive of oligodendrocyte differentiation (diff), and the cells were grown for a further $24 \mathrm{hr}$. This medium was then removed and replaced with the same medium, either with $(\# 1)$ or without (\#2) testicular hyaluronidase $(50 \mu \mathrm{g} / \mathrm{ml})$ for $1 \mathrm{hr}$. This medium was removed and replaced with the same medium, except that the enzyme was added to the flask not previously treated with hyaluronidase (\#2), but not to flask $\# 1$. The conditioned media were concentrated and treated with chondroitinase $\mathrm{ABC}$. An equal volume of each was run under nonreducing conditions in a $4 \%$ gel (for versican and neurocan) or under reducing conditions in a $7 \%$ gel (brevican) and transferred to nitrocellulose. The blots were labeled with the anti-versican mAb 12C5, the anti-neurocan $\mathrm{mAb} 1 \mathrm{G} 2$, or an anti-brevican mAb. Versican, but not neurocan or brevican, was released intact from pre-oligodendrocytes by hyaluronidase. The amount of versican detected in the conditioned medium of differentiating OLCs was greater than that in dividing cells. This was not the case for either neurocan or brevican.
} 
$1 \mathrm{hr}$ incubation was initiated in which hyaluronidase was added to the flask (flask 2) that had not previously received it. The various media were then assayed for the presence of versican by Western blotting with the $12 \mathrm{C} 5 \mathrm{mAb}$. The addition of testicular hyaluronidase brought about the release of intact versican into the medium of pre-oligodendrocytes (Fig. $4 g$ ). No versican was released in the absence of the enzyme. That the hyaluronidase-released versican comigrated with the versican normally present in the conditioned medium is important, because it indicates that the release did not occur as a result of proteolysis of the versican core protein (Fig. $4 g$ ). Versican was not detected in detergent lysates prepared after exposure to hyaluronidase, indicating that all of the cell surface versican is removed by the enzyme. Two other CS-PGs with HA-binding domains, neurocan and brevican, were both detectable in the conditioned medium of these cells, yet neither was released by hyaluronidase (Fig. $4 g$ ). This phenomenon is not connected with link protein, which stabilizes the binding of aggrecan to HA in cartilage, because no link protein was detectable in these cells (data not shown).

\section{Adult rat brain}

We then asked whether versican is bound to HA in the adult rat brain. Serial extracts were prepared from whole rat brains in PBS, $\mathrm{pH}$ 5.3, in the manner described in Materials and Methods. The pellet was resuspended in the same buffer and divided into two equal parts, to only one of which was added testicular hyaluronidase $(50 \mu \mathrm{g} / \mathrm{ml})$. Both homogenates, one with and the other without the enzyme, were incubated for $2 \mathrm{hr}$ at $37^{\circ} \mathrm{C}$. An aliquot was removed from each after $30 \mathrm{~min}$. The homogenates were then washed twice and incubated for a further $2 \mathrm{hr}$, this time with hyaluronidase added to the homogenate not previously exposed to the enzyme. All the resultant supernatants were then tested for the presence of versican by Western blotting with the $12 \mathrm{C} 5 \mathrm{mAb}$.

Substantial amounts of versican $\left(\mathrm{V}_{2}\right)$ were detected in the first PBS extract (Fig. 5, top). The subsequent four PBS extracts were essentially devoid of versican. The release of (additional) versican from the PBS-insoluble material required hyaluronidase. The release of versican was essentially complete after $30 \mathrm{~min}$ at $37^{\circ} \mathrm{C}$, because the amount released after $2 \mathrm{hr}$ was not greater. Importantly, the addition of hyaluronidase to the homogenate initially incubated without the enzyme (and from which little versican had been released) led to the release of versican, indicating that versican release was not simply a consequence of prolonged incubation at $37^{\circ} \mathrm{C}$. Because the amount of versican released by the enzyme was approximately equal to that detected in the first PBS extract, we may conclude that approximately half of the versican in the adult rat brain is bound to HA. As was the case with the cultured cells, the hyaluronidase-released versican comigrated with the versican present in the first PBS extract, implying that the release is mediated by HA degradation and not by proteolysis of the versican core protein.

\section{Versican colocalizes with and is physically associated with tenascin- $R$ in oligodendrocytes}

\section{Immunocytochemistry}

At all stages of oligodendrocyte differentiation, labeling for tenascin-R appeared very similar to that for versican. Labeling for tenascin- $\mathrm{R}$ gave rise to both the ring-type and the substrateassociated stellate profiles. Double labeling of OPCs maintained for $1 \mathrm{~d}$ in differentiation medium (i.e., pro-oligodendroblasts) with the $12 \mathrm{C} 5$ anti-versican $\mathrm{mAb}$ and rabbit anti-tenascin-R revealed an almost identical distribution (Fig. $6 a, b$ ). Doing the

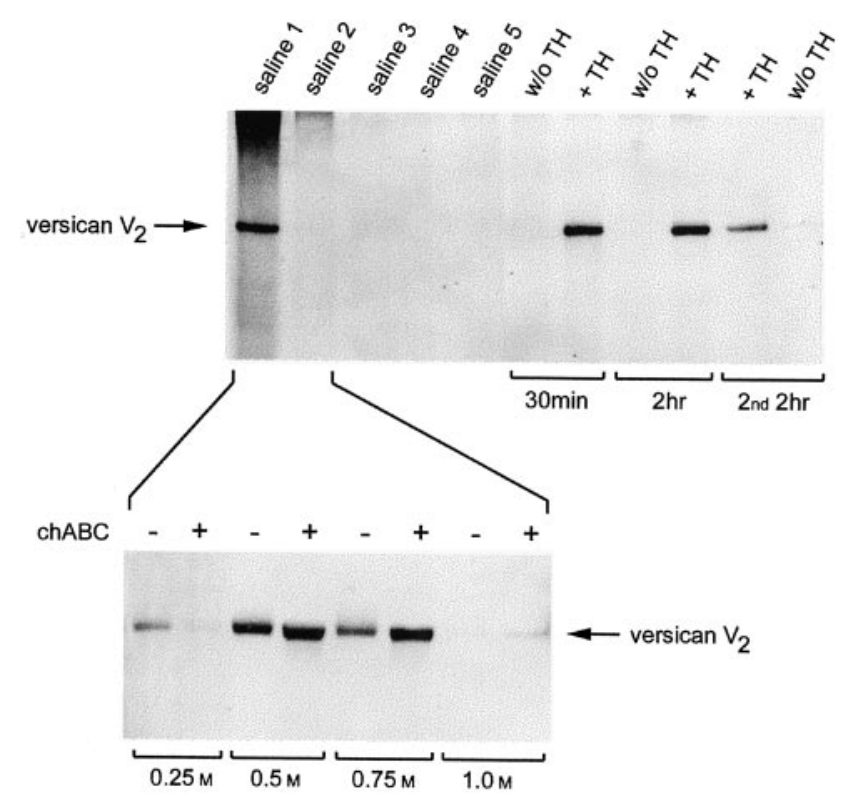

Figure 5. Versican can be released from adult rat brain with hyaluronidase. Top, Serial extracts were prepared from adult rat brain with PBS, $\mathrm{pH}$ 5.3 (saline 1-5). After the fifth PBS extract, the homogenate was divided into two equal parts, to only one of which was added testicular hyaluronidase $(T H)$. The homogenates were incubated at $37^{\circ} \mathrm{C}$ for $2 \mathrm{hr}$. An aliquot was removed from each after $30 \mathrm{~min}$. A second $2 \mathrm{hr}$ incubation was then set up, in which hyaluronidase was added to the homogenate not previously exposed to the enzyme. All extracts were treated with chondroitinase ABC. The volume of each extract was adjusted according to the amount of tissue from which it derived, run in a $4 \%$ gel under nonreducing conditions, and transferred to nitrocellulose. The blot was labeled with the anti-versican mAb $12 \mathrm{C} 5$. Versican was present in the first saline extract, but the release of additional amounts required hyaluronidase. Bottom, The first and second saline extracts were pooled and DEAE cellulose was added. The bound proteins were eluted with increasing concentrations of $\mathrm{NaCl}$. Versican $\left(V_{2}\right)$ bound to the anion exchange resin and was eluted between 0.5 and $0.75 \mathrm{M}$ salt. Chondroitinase brought about a small but discrete shift, indicating that versican $\mathrm{V}_{2}$ carries little chondroitin sulfate.

double labeling in the opposite direction (i.e., the rabbit antitenascin-R first) made no difference to the outcome (i.e., the tenascin- $\mathrm{R}$ antibodies did not inhibit the binding of the versican antibody). As was the case for versican, myelin-forming cells generally labeled poorly, if at all, for tenascin-R, and there was no labeling of the membranous sheets.

The tenascin-R labeling of growth factor-exposed preoligodendrocytes, although identical to that for versican, was essentially unaltered by testicular hyaluronidase, although there was some loss of intensity. This was confirmed by Western blot analysis (Fig. 6c). Although tenascin-R was detected in the medium of hyaluronidase-treated oligodendrocytes (presumably because of continued secretion), the amount was no greater than that found in medium lacking hyaluronidase (Fig. 6c). Furthermore, substantial amounts of tenascin-R were detectable in cell lysates made after hyaluronidase treatment (Fig. 6c). Hence, although the distribution of tenascin- $\mathrm{R}$ is identical to that of versican in these cells, its retention at the cell surface does not depend on hyaluronate.

\section{Coimmunoprecipitation}

Their overlapping distributions in OLCs in vitro and the known ability of (the C-type lectin domain of) versican to bind tenascin-R (Aspberg et al., 1995) led us to ask whether the two 

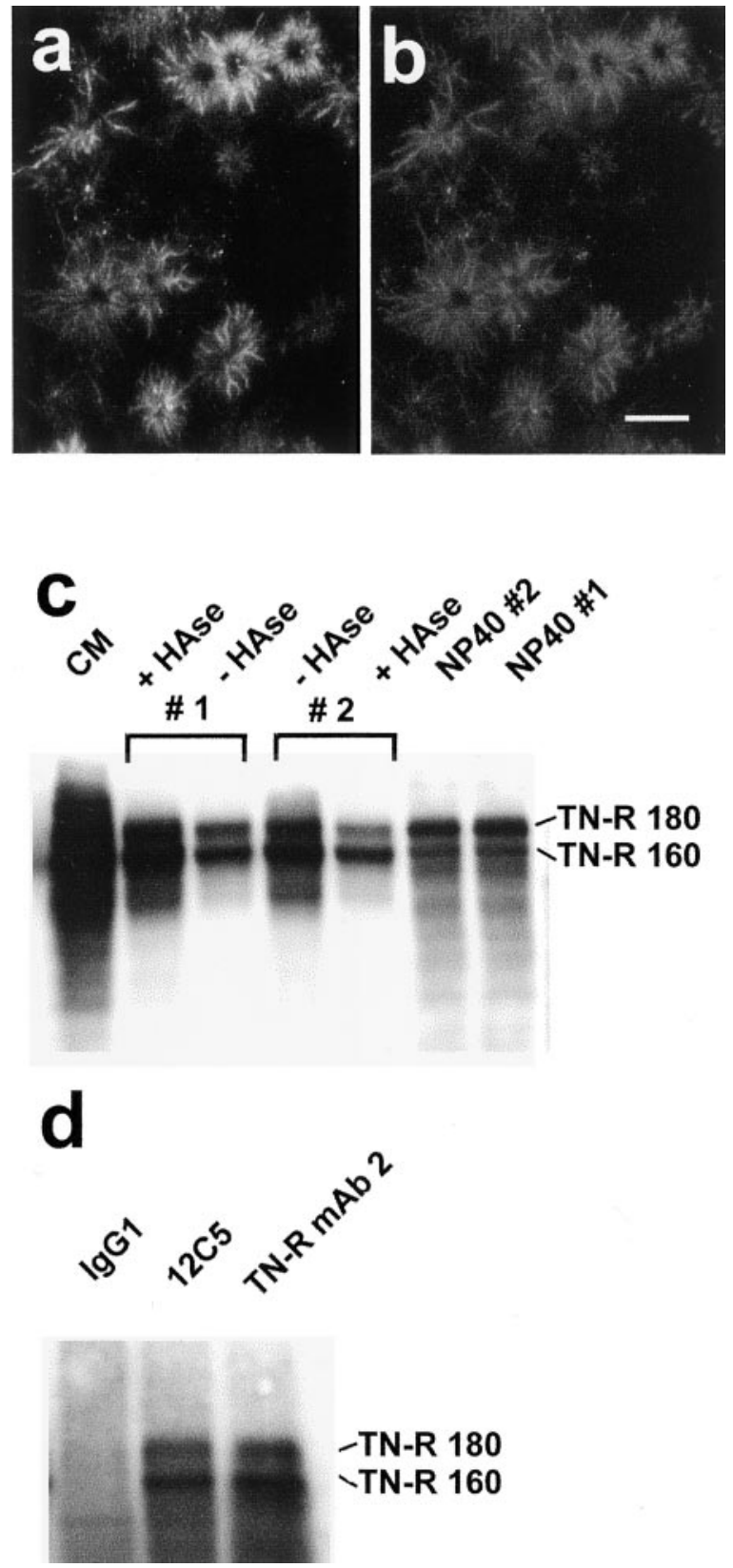

Figure 6. Versican colocalizes with tenascin-R, and the two exist as a complex in oligodendrocyte-conditioned medium. OPCs were grown for $1 \mathrm{~d}$ in differentiation medium and then double labeled with the 12C5 anti-versican $\mathrm{mAb}(a)$ and a polyclonal (rabbit) anti-tenascin-R $(b)$. The distributions of the two appear identical. Scale bar, $25 \mu \mathrm{m}$. $c$, Two flasks of OPCs were grown for $2 \mathrm{~d}$ in differentiation medium. This was then removed and replaced with the same medium, either with (\#1) or without (\#2) testicular hyaluronidase $(50 \mu \mathrm{g} / \mathrm{ml})$ for $1 \mathrm{hr}$. This medium was removed and replaced with the same medium, except that the enzyme was added to the flask not previously treated with the enzyme (\#2), but not to flask \#1. The conditioned media were concentrated and equalized according to the protein content of the (NP-40) cell lysate. The samples were run under reducing conditions in a $7 \%$ gel, transferred to nitrocellulose, and labeled with an anti-tenascin- $\mathrm{R}$ mAb. Large amounts of tenascin- $\mathrm{R}$ were detected in the conditioned medium of oligodendrocytes $(C M)$. Although tenascin- $\mathrm{R}$ was present in the hyaluronidase-treated cells $(\# 1+H A s e)$, the amount was no greater than that present in the conditioned medium of the untreated cells $(\# 2-H A s e)$. The failure of hyaluronidase to release tenascin- $\mathrm{R}$ is also evidenced by the presence of tenascin- $\mathrm{R}$ in the cell lysates (NP40). Note that the smaller tenascin-R 160 predominates in the conditioned media, whereas the $180 \mathrm{kDa}$ form predominates in the cell lysates. $d$, Immunoprecipitation was performed are physically associated in oligodendrocytes. The anti-versican $\mathrm{mAb} 12 \mathrm{C} 5$ was found to immunoprecipitate tenascin- $\mathrm{R}$ from oligodendrocyte-conditioned medium and from the medium of hyaluronidase-treated oligodendrocytes (Fig. $6 d$ ), indicating that the two do exist as a complex. The existence of such a complex in the medium of hyaluronidase-treated oligodendrocytes presumably means that some tenascin- $\mathrm{R}$ was released from the cells by hyaluronidase (accounting for the loss of intensity), but that the majority remained cell associated. Antibodies against tenascin-R were also found to immunoprecipitate versican (data not shown).

\section{Control of versican expression in oligodendrocyte lineage cells}

Our studies on versican expression in cultured CNS glia pointed to oligodendrocyte lineage cells as the likely source of versican in the injured CNS. The increased expression must be brought about, directly or indirectly, by cytokines and growth factors released after injury. Cytokines and growth factors known to be upregulated in response to CNS injury were therefore screened for their effect on versican expression in OLCs. The amount of versican in OLC-conditioned medium was assessed by Western blotting with the $12 \mathrm{C} 5 \mathrm{mAb}$. We examined versican expression in both dividing (i.e., in the presence of PDGF and FGF2) and differentiating OLCs. The samples were equalized according to the protein content of the (NP-40) cell lysate from which the conditioned media were collected.

\section{Dividing OLCs}

OLCs were grown for $24 \mathrm{hr}$ in medium containing PDGF and FGF2. The medium was then changed, and the cells were cultured for a further $2 \mathrm{~d}$ in the presence of PDGF and FGF2 and the cytokine or growth factor under investigation. In the presence of PDGF and FGF2, TGF $\beta$ clearly led to an increase in the amount of versican present (Fig. 7a). The effects of TGF $\beta$ and EGF were investigated in more detail, and those of $\operatorname{TGF} \beta$ were clearly reproduced (Fig. 7b). Versican expression was unaffected by EGF, however.

\section{Differentiating OLCS}

OLCs were grown for $2 \mathrm{~d}$ in medium containing PDGF and FGF2. The medium was then changed to differentiation medium containing the cytokine/growth factor to be tested. Only IL- $1 \beta$ and CNTF consistently brought about an increase in versican expression under these conditions (Fig. 7c).

\section{Chondroitin sulfate proteoglycans contribute to the axon growth-inhibitory properties of oligodendrocytes}

Recently, it has been suggested that chondroitin sulfate proteoglycans are responsible for the growth cone-collapsing activity of oligodendrocytes (Niederöst et al., 1999). Because versican is one of the major CS-PGs expressed by these cells, the implication is that versican is at least partly responsible for this activity. We have investigated whether the axon growth-inhibitory effects of oligodendrocytes, grown under conditions shown to promote

on oligodendrocyte-conditioned medium with an isotype-matched control antibody ( $I g G 1)$, the anti-versican $\mathrm{mAb} 12 \mathrm{C} 5$, or an anti-tenascin-R mAb. The products were run in a $7 \%$ gel under reducing conditions, transferred to nitrocellulose, and labeled with the same anti-tenascin- $\mathrm{R} \mathrm{mAb}$. The anti-versican $\mathrm{mAb}$ immunoprecipitated tenascin- $\mathrm{R}$, indicating that the two are physically associated in oligodendrocyte-conditioned medium. 


\section{a dividing cells}

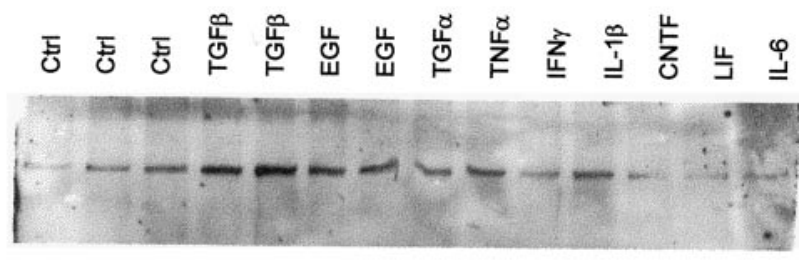

b dividing cells

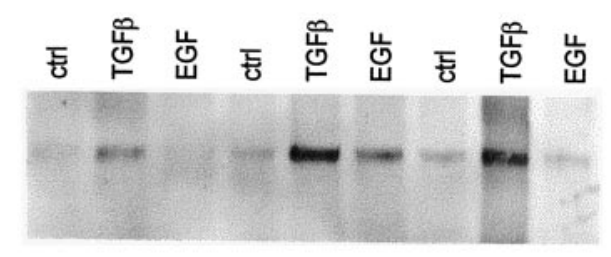

C differentiating cells

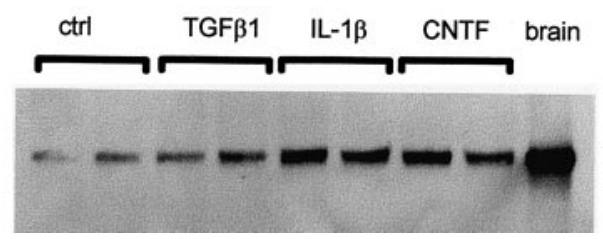

Figure 7. Versican is upregulated by TGF $\beta$ in dividing OPCs and by IL-1 $\beta$ and CNTF in differentiating oligodendrocytes. Dividing cells were maintained for $2 \mathrm{~d}$ in medium containing PDGF and FGF2 and the cytokine/growth factor $(10 \mathrm{ng} / \mathrm{ml})$ being tested $(a, b)$. Differentiating cells were grown for $2 \mathrm{~d}$ in medium containing PDGF and FGF2, and then for a further $2 \mathrm{~d}$ in differentiation medium containing the cytokine/growth factor $(10 \mathrm{ng} / \mathrm{ml})$ under investigation $(c)$. The conditioned media were collected, concentrated, and treated with chondroitinase ABC. The samples were equalized according to the protein content of the cell lysates, run under nonreducing conditions in a $4 \%$ gel, and transferred to nitrocellulose. The blots were labeled with the anti-versican mAb 12C5. TGF $\beta$ led to an increase in the amount of versican present in the conditioned media of dividing OPCs $(a, b)$. In differentiating cells, IL- $1 \beta$ and CNTF, but not TGF $\beta$, brought about an increase in the amount of versican in the conditioned medium (c).

maximal versican expression, can be alleviated by the removal of chondroitin sulfate.

The enzyme chondroitinase $\mathrm{ABC}$ was used to remove chondroitin sulfate from the environs of differentiating oligodendrocytes. Oligodendrocyte progenitor cells were grown for $36 \mathrm{hr}$ in differentiation medium, resulting in the deposition of versican on the substrate. It should be noted that these cells do not form a confluent monolayer and that versican is deposited on the substrate in the spaces between the cells. The cells were treated with chondroitinase $\mathrm{ABC}$ for the final $3 \mathrm{hr}$ and then fixed in $4 \%$ paraformaldehyde. The cells were fixed to prevent further differentiation of the OPCs and concomitant loss of versican immunoreactivity during the course of the axon growth assay $(2 \mathrm{~d})$. The effectiveness of the chondroitinase digestion was assessed with the 2B6 $\mathrm{mAb}$, which recognizes the stubs remaining on the core protein after chondroitinase digestion of chondroitin sulfate
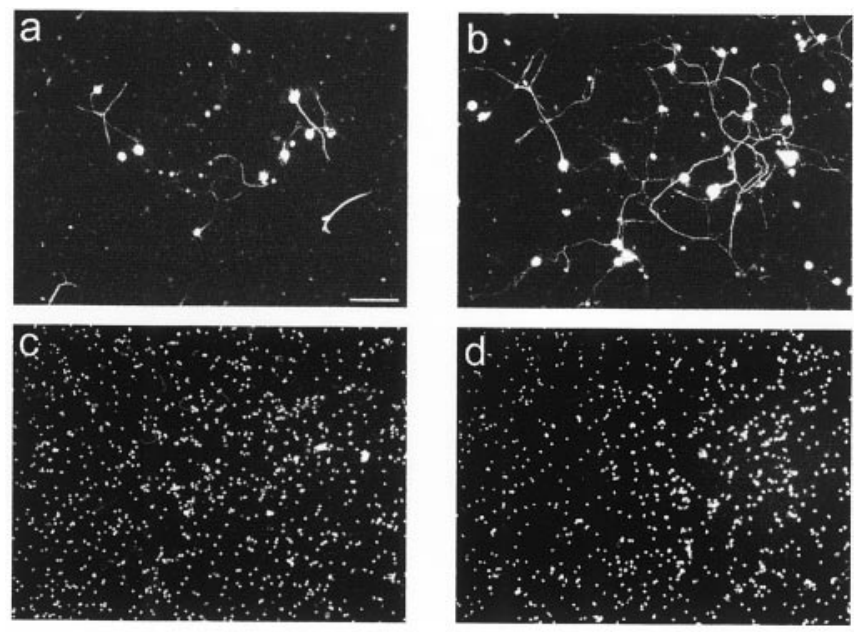

e

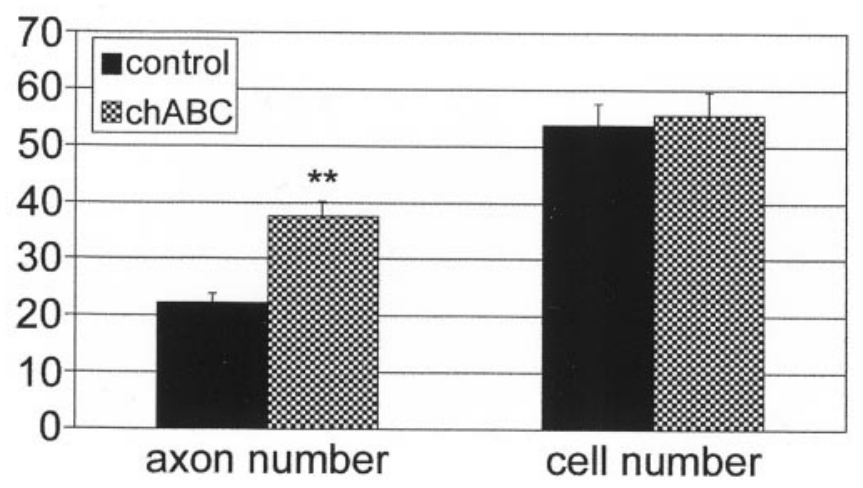

Figure 8. Chondroitin sulfate proteoglycans contribute to the axon growth-inhibitory properties of oligodendrocytes. Dorsal root ganglion neurons growing on untreated $(a, c)$ and chondroitinase ABC-treated $(b$, d) paraformaldehyde-fixed pro-oligodendroblasts were labeled with 3A10 $(a, b)$ and Hoechst 33342 to visualize nuclei $(c, d)$. Scale bar, $100 \mu \mathrm{m} . e$, Quantification of neurite outgrowth on pro-oligodendroblasts. Chondroitinase treatment led to a significant increase in DRG neurite outgrowth $(* * p<0.001$; Student's $t$ test) without affecting neuronal adhesion to the substrate. These findings suggest that axon growth in an oligodendroglial environment is impaired by chondroitin sulfate.

GAG chains. The digested and fixed cells were used as a substrate for the growth of dissociated DRG neurons. Removal of the chondroitin sulfate, much of which will be carried by versican, led to a significant increase in neurite outgrowth (Fig. 8). Neuronal adhesion to the substrate was not affected by chondroitinase treatment (Fig. 8). This assay was performed on three separate occasions, with the same outcome. Hence, the removal of chondroitin sulfate alleviates the axon growth-inhibitory properties of immature oligodendrocytes.

\section{DISCUSSION}

\section{Versican is upregulated in the injured CNS}

In the adult rat brain, immunohistochemistry has shown there to be high levels of versican in white matter tracts (Bignami et al., 1993). In gray matter, versican expression is more variable. Although it is readily detectable in spinal cord gray matter, very little versican is detectable in the cerebral cortex (Bignami et al., 1993). Here, we demonstrate a substantial increase in versican immunoreactivity around a knife lesion to the cerebral cortex, and Western blot analysis of extracts prepared from injured and 
uninjured tissue revealed there to be two to three times more versican in the injured tissue. The injury-induced versican comigrated (at $400 \mathrm{kDa}$ ) with that in the normal, uninjured rat brain and is therefore the $\mathrm{V}_{2}$ isoform. Rat CNS versican has been shown to carry little chondroitin sulfate (Asher et al., 1995). The injury-induced versican migrated as a single, discrete band without chondroitinase treatment and comigrated with normal rat brain versican, indicating that it too carries little chondroitin sulfate. The axon growth-inhibitory properties of brain-derived versican have been shown to reside in both the core protein and the chondroitin sulfate GAG chains (Schmalfeldt et al., 2000). Despite its relatively low level of glycanation, therefore, the injury-induced versican would be expected to exert an inhibitory effect on regenerating axons in the injured CNS.

\section{Versican is a product of oligodendrocyte lineage cells}

The distribution of versican in the normal (Bignami et al., 1993) and injured CNS is indicative of a glial origin. We have screened various glial cell types for versican expression. Versican was present in the conditioned media of OLCs and meningeal cells, but not in that of astrocytes or microglia. However, although meningeal cells produced the $\mathrm{V}_{0}$ and $\mathrm{V}_{1}$ isoforms of versican, OLCs were only capable of producing the smaller $V_{2}$ isoform. OLCs, then, are uniquely capable of producing the isoform that predominates in the normal and injured CNS, and this suggests that they are the major source of CNS versican. Although cultured OLCs make the same isoform of versican as that found in the CNS, OLC-derived versican was unable to enter a $4 \%$ gel without previous chondroitinase treatment. OLC-derived versican therefore carries large amounts of chondroitin sulfate. The pattern of versican expression in the normal and injured CNS is entirely consistent with it being produced by OLCs, which are recruited to lesions in large numbers (Levine et al., 2001).

\section{Versican expression increases in differentiating OLCs}

Western blot analysis of conditioned medium revealed there to be higher levels of versican in differentiating oligodendrocytes than in dividing progenitor cells. Furthermore, no versican labeling was seen in dividing, bipolar OPCs. The labeling of large numbers of cells occurred only after the removal of the growth factors and was seen only on or around multipolar cells. These observations suggest that versican expression in OLCs requires some differentiation or their exit from the division cycle or both. Versican labeling was first seen at the late A2B5-positive stage, suggesting that versican expression begins at this early stage. Previously, it has been reported that oligodendrocytes label for versican $\mathrm{V}_{2}$ (Niederöst et al., 1999). Our data are in agreement with this conclusion and show, furthermore, that cells of the oligodendrocyte lineage acquire the ability to produce versican at an early stage in their differentiation.

\section{Versican is bound to hyaluronate in vitro and in vivo}

Any attempt to remove versican from the injured CNS will require an understanding of how, and with what, it interacts in the ECM. In common with the other members of the aggrecan family, versican possesses a hyaluronate-binding domain at its N-terminal (Zimmermann and Ruoslahti, 1989) and has been shown to bind to hyaluronate in vitro (LeBaron et al., 1992).

Two types of labeling were seen in OLCs in vitro: substrateassociated, stellate profiles and ring-like labeling of the cell body. As noted above, both first appeared at the same stage (i.e., late A2B5 positive). The substrate-associated labeling was the predominant pattern in OLCs plated directly in differentiation me- dium (i.e., not exposed to growth factors), whereas the ring-type labeling was the predominant pattern in differentiating cells that had been exposed to growth factors. The question arises then as to why the ring-type labeling becomes more prevalent in growth factor-treated cells. The labeling of the cells is indicative not only of the ability of the cell to make versican, but also its ability to retain it at the cell surface. The ability of OLCs to retain versican is dependent on HA, because (1) labeling for HA gave rise to a pattern identical to that for versican, (2) the ring-type versican labeling was sensitive to hyaluronidase, and (3) hyaluronidase brought about the release of intact versican into the medium. Hyaluronate synthesis increases in dividing cells (Laurent and Fraser, 1992), and this explains why growth factor-driven OLCs retain versican at their surface. Although versican binding to these growth factor-driven cells is entirely HA dependent, versican binding to the substrate is not.

It was possible to solubilize approximately half of the versican in the adult rat brain with PBS. Hyaluronidase brought about the release of additional versican, after which no further versican could be extracted with SDS. The amount released by the enzyme was roughly equal to that solubilized by PBS. Hence, approximately half of the versican in the adult rat brain exists in association with HA. Preliminary data suggest that HA itself is upregulated in the injured CNS (R. A. Asher, D. A. Morgenstern, and J. W. Fawcett, unpublished observations) and could therefore play a pivotal role in anchoring versican and other HA-binding CS-PGs (e.g., neurocan) in the glial scar.

\section{A versican/tenascin-R complex exists in oligodendrocytes}

Versican also has the ability to interact with tenascin-R, via its C-type lectin domain (Aspberg et al., 1995). Here we have shown that tenascin-R colocalizes with versican in OLCs and that antibodies against one can immunoprecipitate the other. Hence, some of the versican and tenascin-R produced by these cells exists as a complex. Such a complex may well be present in the lesion environment, because transection of the postcommissural fornix led to an increase in tenascin-R expression (Probstmeier et al., 2000). The properties of the ECM as a whole may not be entirely explicable in terms of its constituent parts. For this reason, an understanding of how, and with what, each component interacts in the glial scar will be important.

\section{Regulation of versican expression in OLCs}

TGF $\beta$ brought about an increase in the amount of versican detected in the conditioned medium of dividing OPCs, and IL- $1 \beta$ and CNTF brought about an increase in differentiating cells. Such studies are complicated by the fact that versican expression increases as these cells differentiate. Because TGF $\beta$ is known to promote differentiation in these cells (McKinnon et al., 1993), it is possible that the increase in versican expression is an indirect consequence of TGF $\beta$-induced differentiation, rather than a direct effect on versican expression. Nevertheless, the ability of TGF $\beta$ to bring about an increase in versican expression suggests that it may also play some part in the upregulation of versican in the injured CNS.

\section{Oligodendrocyte-derived chondroitin sulfate (proteoglycans) inhibit axon growth}

Recently, it has been shown that the growth cone-collapsing activity of oligodendrocytes is related to the presence of CS-PGs (Niederöst et al., 1999). Growth of these cells in the presence of $\beta$-D-xyloside, an inhibitor of GAG synthesis, led to the disappear- 
ance of versican at the cell surface and to the loss of contactmediated growth cone-collapse (Niederöst et al., 1999). Our data also point to an inhibitory role for CS-PG GAG chains in axon growth in an oligodendroglial environment, because the removal of chondroitin sulfate led to an increase in axon growth on oligodendrocytes grown under conditions shown to favor versican expression and glycanation. It has been reported that immature oligodendrocytes do not induce growth cone collapse (Schwab and Caroni, 1988). The cells used in our bioassay were mostly A2B5 negative and expressed versican at much higher levels than the (A2B5-positive) cells reported previously not to induce growth cone collapse. Regardless of their precise stage, our data suggest something rather different, namely that immature oligodendrocytes create an environment (i.e., ECM) that is unsupportive of axon growth, without the need to induce growth cone collapse.

Previously, we have shown that DRG neurons growing on a monolayer of living Neu7 cells do not avoid patches of versican (Fidler et al., 1999). However, these patches also contained laminin, and this may have been sufficient to override the inhibitory effects of versican.

\section{Conclusions}

Here we show that versican, an axon growth-inhibitory CS-PG, is upregulated in the injured CNS and is therefore present in the environment in which axon regeneration fails. We have identified oligodendrocyte lineage cells as the likely source of this versican and now believe these cells to be a major source of axon growthinhibitory CS-PGs in the damaged CNS. Oligodendrocyte lineage cells are present throughout the normal adult CNS and are recruited to injuries in large numbers (Levine et al., 2001). These cells express the inhibitory CS-PG NG2 at their surface (Levine, 1994) and release proteolytically shed forms of it into the lesion environment (Morgenstern, 2000). These cells are also active in the synthesis of neurocan (Asher et al., 2000), phosphacan (Canoll et al., 1996), brevican (Seidenbecher et al., 1998; present work), and tenascin-R (Pesheva et al., 1997), all of which exert inhibitory effects on neurite outgrowth in vitro (Pesheva et al., 1993; Friedlander et al., 1994; Yamada et al., 1997; Garwood et al., 1999). A possible strategy for encouraging axon regeneration, therefore, would be to prevent the recruitment of OLCs to CNS injuries. Complement killing with gal-C antibodies, which would be expected to target versican-producing cells, has in fact been shown to promote axon regeneration in the rat spinal cord (Dyer et al., 1998). Also, the inf usion of an anti-mitotic into the lesioned nigrostriatal tract prevented OLC recruitment and promoted axon regeneration (Rhodes et al., 2000).

\section{REFERENCES}

Asher R, Perides G, Vanderhaeghen J-J, Bignami A (1991) Extracellular matrix of central nervous system white matter: demonstration of a hyaluronate-protein complex. J Neurosci Res 28:410-421.

Asher RA, Scheibe RJ, Keiser HD, Bignami A (1995) On the existence of a cartilage-like proteoglycan and link proteins in the central nervous system. Glia 13:294-308.

Asher RA, Morgenstern DA, Adcock KH, Rogers JH, Fawcett JW (1999) Versican is up-regulated in CNS injury and is a product of O-2A lineage cells. Soc Neurosci Abstr 25:750.

Asher RA, Morgenstern DA, Fidler PS, Adcock KH, Oohira A, Braistead JE, Levine JM, Margolis RU, Rogers JH, Fawcett JW (2000) Neurocan is upregulated in injured brain and in cytokine-treated astrocytes. J Neurosci 20:2427-2438.

Aspberg A, Binkert C, Ruoslahti E (1995) The versican C-type lectin domain recognizes the adhesion protein tenascin-R. Proc Natl Acad Sci USA 92:10590-10594.

Aspberg A, Adam S, Kostka G, Timpl R, Heinegård D (1999) Fibulin-1 is a ligand for the C-type lectin domains of aggrecan and versican. J Biol Chem 274:20444-20449.

Barker RA, Dunnett SB, Faissner A, Fawcett JW (1996) The time course of loss of dopaminergic neurons and the gliotic reaction surrounding grafts of embryonic mesencephalon to the striatum. Exp Neurol 141:79-93.

Bignami A, Perides G, Rahemtulla F (1993) Versican, a hyaluronatebinding proteoglycan of embryonal precartilagenous mesenchyma, is mainly expressed postnatally in rat brain. J Neurosci Res 34:97-106.

Bradbury EJ, Bennett GS, Moon LDF, Patel PN, Fawcett JW, McMahon SB (2000) Chondroitinase ABC delivered to the site of a spinal cord injury upregulates GAP-43 expression in dorsal root ganglion neurons. Soc Neurosci Abstr 26:860.

Brittis PA, Canning DR, Silver J (1992) Chondroitin sulfate as a regulator of neuronal patterning in the retina. Science 255:733-736.

Canoll PD, Petanceska S, Schlessinger J, Musacchio JM (1996) Three forms of RPTP- $\beta$ are differentially expressed during gliogenesis in the developing rat brain and during glial cell differentiation in culture. J Neurosci Res 44:199-215.

Davies SJA, Fitch MT, Memberg SP, Hall AK, Raisman G, Silver J (1997) Regeneration of adult axons in white matter tracts of the central nervous system. Nature 390:680-683.

Davies SJA, Goucher DR, Doller C, Silver J (1999) Robust regeneration of adult sensory axons in degenerating white matter of the adult rat spinal cord. J Neurosci 19:5810-5822.

Deller T, Haas CA, Naumann T, Joester A, Faissner A, Frotscher M (1997) Up-regulation of astrocyte-derived tenascin-C correlates with neurite outgrowth in the rat dentate gyrus after unilateral entorhinal cortex lesion. Neuroscience 81:829-846.

Dou C-L, Levine JM (1994) Inhibition of neurite growth by the NG2 chondroitin sulfate proteoglycan. J Neurosci 14:7616-7628.

Dours-Zimmermann MT, Zimmermann DR (1994) A novel glycosaminoglycan attachment domain identified in two alternative splice variants of human versican. J Biol Chem 269:32992-32998.

Dyer JK, Bourque JA, Steeves JD (1998) Regeneration of brain stemspinal axons after lesion and immunological disruption of myelin in adult rat. Exp Neurol 154:12-22.

Emerling DE, Lander AD (1996) Inhibitors and promoters of thalamic neuron adhesion and outgrowth in embryonic neocortex: functional association with chondroitin sulfate. Neuron 17:1089-1100.

Fidler PS, Schuette K, Asher RA, Dobbertin A, Thornton SR, CallePatino Y, Muir B, Levine JM, Geller HM, Rogers JH, Faissner A, Fawcett JW (1999) Comparing astrocytic cell lines that are inhibitory or permissive for axon growth: the major axon-inhibitory proteoglycan is NG2. J Neurosci 19:8778-8788.

Fitch MT, Silver J (1997) Activated macrophages and the blood-brain barrier: inflammation after CNS injury leads to increases in putative inhibitory molecules. Exp Neurol 148:587-603.

Friedlander DR, Milev P, Karthikeyan L, Margolis RK, Margolis RU, Grumet M (1994) The neuronal chondroitin sulfate proteoglycan neurocan binds to the neural cell adhesion molecules Ng-CAM/L1/NILE and N-CAM, and inhibits neuronal adhesion and neurite outgrowth. J Cell Biol 125:669-680.

Gard AL, Williams WC, Burrell MR (1995) Oligodendroblasts distinguished from O-2A glial progenitors by surface phenotype $\left(\mathrm{O}^{+}{ }^{+} \mathrm{GalC}^{-}\right)$and response to cytokines using signal transducer LIFR $\beta$. Dev Biol 167:596-608.

Garwood J, Schnädelbach O, Clement A, Schütte K, Bach A, Faissner A (1999) DSD-1-proteoglycan is the mouse homolog of phosphacan and displays opposing effects on neurite outgrowth dependent on neuronal lineage. J Neurosci 19:3888-3899.

Gates MA, Fillmore H, Steindler DA (1996) Chondroitin sulfate proteoglycan and tenascin in the wounded adult mouse neostriatum in vitro: dopamine neuron attachment and process outgrowth. J Neurosci 16:8005-8018.

Haas CA, Rauch U, Thon N, Merten T, Deller T (1999) Entorhinal cortex lesion in adult rats induces the expression of the neuronal chondroitin sulfate proteoglycan neurocan in reactive astrocytes. J Neurosci 19:9953-9963.

Jaworski DM, Kelly GM, Hockfield S (1999) Intracranial injury acutely induces the expression of the secreted isoform of the CNS-specific hyaluronan-binding protein $\mathrm{BEHAB} /$ brevican. Exp Neurol 157: 327-337.

Laurent TC, Fraser JRF (1992) Hyaluronan. FASEB J 6:2397-2404.

Laywell ED, Steindler DA (1991) Boundaries and wounds, glia and glycoconjugates. Cellular and molecular analyses of developmental partitions and adult brain lesions. Ann NY Acad Sci 633:122-141.

LeBaron RG, Zimmermann DR, Ruoslahti E (1992) Hyaluronate binding properties of versican. J Biol Chem 267:10003-10010.

Levine JM (1994) Increased expression of the NG2 chondroitin-sulfate proteoglycan after brain injury. J Neurosci 14:4716-4730.

Levine JM, Reynolds R, Fawcett JW (2001) The oligodendrocyte precursor cell in health and disease. Trends Neurosci 24:39-47.

Lips K, Stichel CC, Müller HW (1995) Restricted appearance of tenascin and chondroitin sulphate proteoglycans after transection and 
sprouting of adult rat postcommissural fornix. $\mathrm{J}$ Neurocytol 24:449-464.

McKeon RJ, Schreibe RC, Rudge JS, Silver J (1991) Reduction of neurite outgrowth in a model of glial scarring following CNS injury is correlated with the expression of inhibitory molecules on reactive astrocytes. J Neurosci 11:3398-3411.

McKeon RJ, Höke A, Silver J (1995) Injury-induced proteoglycans inhibit the potential for laminin-mediated axon growth on astrocytic scars. Exp Neurol 136:32-43.

McKeon RJ, Jurynec MJ, Buck CR (1999) The chondroitin sulfate proteoglycans neurocan and phosphacan are expressed by reactive astrocytes in the chronic CNS glial scar. J Neurosci 19:10778-10788.

McKinnon RD, Piras G, Ida JA, Dubois-Dalcq M (1993) A role for TGF- $\beta$ in oligodendrocyte differentiation. J Cell Biol 121:1397-1407.

Milev P, Friedlander DR, Sakurai T, Karthikeyan L, Flad M, Margolis RK, Grumet M, Margolis RU (1994) Interactions of the chondroitin sulfate proteoglycan phosphacan, the extracellular domain of a receptor-type protein tyrosine phosphatase, with neurons, glia, and neural cell adhesion molecules. J Cell Biol 127:1703-1715.

Miura R, Aspberg A, Ethell IM, Hagihara K, Schnaar RL, Ruoslahti E, Yamaguchi Y (1999) The proteoglycan lectin domain binds sulfated cell surface glycolipids and promotes cell adhesion. J Biol Chem 274:11431-11438.

Moon LDF, Asher RA, Rhodes KE, Fawcett JW (2001) Regeneration of CNS axons back to their target following treatment of adult rat brain with chondroitinase ABC. Nat Neurosci 4:465-466.

Morgenstern DA (2000) Chondroitin sulphate proteoglycans in the peripheral and central nervous systems. $\mathrm{PhD}$ thesis, University of Cambridge.

Niederöst BP, Zimmermann DR, Schwab ME, Bandtlow CE (1999) Bovine CNS myelin contains neurite growth-inhibitory activity associated with chondroitin sulfate proteoglycans. J Neurosci 19:8979-8989.

Oakley RA, Tosney KW (1991) Peanut agglutinin and chondroitin-6sulfate are molecular markers for tissues that act as barriers to axon advance in the avian embryo. Dev Biol 147:187-206.

Ohya T, Kaneko Y (1970) Novel hyaluronidase from Streptomyces. Biochim Biophys Acta 198:607-609.

Oohira A, Matsui F, Watanabe E, Kushima Y, Maeda N (1994) Developmentally regulated expression of a brain specific species of chondroitin sulfate proteoglycan, neurocan, identified with a monoclonal antibody $1 \mathrm{G} 2$ in the rat cerebrum. Neuroscience 60:145-157.

Perides G, Lane WS, Andrews D, Dahl D, Bignami A (1989) Isolation and partial characterization of a glial hyaluronate-binding protein. J Biol Chem 264:5981-5987.

Perides G, Asher RA, Lark MW, Lane WS, Robinson RA, Bignami A (1995) Glial hyaluronate-binding protein: a product of metalloproteinase digestion of versican? Biochem J 312:377-384.

Pesheva P, Spiess E, Schachner M (1989) J1-160 and J1-180 are oligodendrocyte-secreted nonpermissive substrates for cell adhesion. J Cell Biol 109:1765-1778.

Pesheva P, Gennarini G, Goridis C, Schachner M (1993) The F3/11 cell adhesion molecule mediates the repulsion of neurons by the extracellular matrix glycoprotein J1-160/180. Neuron 10:69-82.

Pesheva P, Gloor S, Schachner M, Probstmeier R (1997) Tenascin-R is an intrinsic autocrine factor for oligodendrocyte differentiation and promotes cell adhesion by a sulfatide-mediated mechanism. J Neurosci 17:4642-4651.

Pindzola RR, Doller C, Silver J (1993) Putative inhibitory extracellular matrix molecules at the dorsal root entry zone of the spinal cord during development and after root and sciatic nerve lesions. Dev Biol 156:34-48.

Probstmeier R, Stichel CC, Müller HW, Asou H, Pesheva P (2000) Chondroitin sulfates expressed on oligodendrocyte-derived tenascin-R are involved in neural cell recognition. Functional implications during CNS development and regeneration. J Neurosci Res 60:21-36.

Rhodes KE, Moon LDF, Fawcett JW (2000) Inhibiting proliferation in glial scar formation: effects on axon regeneration in the CNS. Soc Neurosci Abstr 26:856.

Schmalfeldt M, Dours-Zimmermann MT, Winterhalter KH, Zimmermann DR (1998) Versican $V_{2}$ is a major extracellular matrix component of the mature bovine brain. J Biol Chem 273:15758-15764.

Schmalfeldt M, Bandtlow CE, Dours-Zimmermann MT, Winterhalter KH, Zimmermann DR (2000) Brain derived versican V2 is a potent inhibitor of axonal growth. J Cell Sci 113:807-816.

Schwab ME, Caroni P (1988) Oligodendrocytes and CNS myelin are nonpermissive substrates for neurite growth and fibroblast spreading in vitro. J Neurosci 8:2381-2393.

Seidenbecher CI, Gundelfinger ED, Böckers TM, Trotter J, Kreutz MR (1998) Transcripts for secreted and GPI-anchored brevican are differentially distributed in rat brain. Eur J Neurosci 10:1621-1630.

Serafini T, Colamarino SA, Leonardo ED, Wang H, Beddington $\mathrm{R}$, Skarnes WC, Tessier-Lavigne M (1996) Netrin-1 is required for commissural axon guidance in the developing vertebrate nervous system. Cell 87:1001-1014.

Skaper SD, Facci L, Milani D, Leon A, Toffano G (1990) Culture and use of primary and clonal neural cells. In: Methods in neurosciences, Vol 2 (Conn PM, ed), pp 17-33. San Diego: Academic.

Snow DM, Lemmon V, Carrino DA, Caplan AI, Silver J (1990) Sulfated proteoglycans in astroglial barriers inhibit neurite outgrowth in vitro. Exp Neurol 109:111-130.

Thon N, Haas CA, Rauch U, Merten T, Fässler R, Frotscher M, Deller T (2000) The chondroitin sulphate proteoglycan brevican is upregulated by astrocytes after entorhinal cortex lesions in adult rats. Eur J Neurosci 12:2547-2558.

Yamada H, Fredette B, Shitara K, Hagihara K, Miura R, Ranscht B, Stallcup WB, Yamaguchi Y (1997) The brain chondroitin sulfate proteoglycan brevican associates with astrocytes ensheathing cerebellar glomeruli and inhibits neurite outgrowth from granule neurons. J Neurosci 17:7784-7795.

Zimmermann DR, Ruoslahti E (1989) Multiple domains of the large fibroblast proteoglycan, versican. EMBO J 8:2975-2981. 